\title{
Pengaruh Penambahan Serbuk Biji Alpukat (Persea Americana Mill) Terhadap Penurunan Bilangan Peroksida Pada Minyak Goreng Curah
}

\author{
Nurminha, Sri Nuraini \\ Jurusan Analis Kesehatan Politeknik Kesehatan Tanjungkarang
}

\begin{abstract}
Abstrak
Minyak goreng yang digunakan berulang untuk menggoreng berbagai jenis makanan dapat menyebabkan kerusakan pada minyak. Bilangan Peroksida salah satu indikator kerusakan minyak goreng. Untuk menurunkan bilangan peroksida dengan menambahkan antioksidan kedalam minyak goreng. Biji alpukat (Persea Americana Mill) memiliki aktivitas antioksidan 93,037 \% dan mengandung flavonoid dan polifenol dan bersifat sebagai antibakteri dan anti kanker. Tujuan penelitian untuk mengetahui pengaruh penambahan serbuk biji alpukat terhadap penurunan bilangan peroksida pada minyak goreng curah dengan variasi konsentrasi 0,$5 ; 10 ; 15 ; 20 ; 30$ dan $40 \%$, lama pengadukan 30, 60, 90 dan 120 menit. Desain penelitian eksperimantal. Waktu penelitian bulan Juli-November 2018. Analisa data menggunakan uji Anova. Hasil penelitian didapatkan bilangan peroksida pada minyak goreng curah sebelum pemanasan 4,85 mek $\mathrm{O}_{2} / \mathrm{kg}$ dan setelah pemanasan $18,56 \mathrm{mek} \mathrm{O}_{2} / \mathrm{kg}_{\mathrm{gada}}$ minyak goreng curah sebelum penambahan serbuk biji alpukat. Bilangan peroksida minyak goreng curah setelah penambahan serbuk biji alpukat didapatkan hasil maksimal pada konsentari $40 \%$ dengan waktu pengadukan 120 menit yaitu 5,8 mekO $2 / \mathrm{kg}$. Kesimpulan ada pengaruh penambahan serbuk biji alpukat (Persea Americana Mill) yang signifikan antara waktu pengadukan dengan penurunan bilangan peroksida pada minyak goreng curah $\mathrm{p}$ value 0.000 .
\end{abstract}

Kata Kunci : minyak goreng, biji alpukat, bilangan peroksida

\section{The Effect of Powder Addition Avocado Seeds (Persea Americana Mill) On Decreasing Peroxide Numbers In Bulk Cooking Oil}

\begin{abstract}
Cooking oil that is used repeatedly to fry various types of food can cause damage to cooking oil because of changes in its chemical composition. Peroxide number is an indicator of damage to cooking oil. Avocado (Persea Americana Mill) seeds have antioxidant activity 93,037\% because they contain flavonoids and polyphenols and are antibacterial and anti-cancer. The purpose of this research was to determine the effect of adding avocado seed powder to the reduction of peroxide numbers in used cooking oil with a concentration of 0 ; $5 ; 10 ; 15 ; 20,30,40 \%$ and stirring time 30, 60, 90 and 120 minutes. The research design was experimental. The research was conducted in July-November 2018. Data analysis was performed using the ANOVA test. The results showed that peroxide number in bulk cooking oil before heating was 4.85 meq $\mathrm{O}_{2} / \mathrm{kg}$ and after heating 18.56 meats of $\mathrm{O}_{2} / \mathrm{kg}$ in bulk cooking oil before being treated with avocado seed powder. Peroxide numbers in bulk cooking oil after the addition of avocado seed powder by looking at variations in stirring time and concentration, the maximum yield at $40 \%$ concentration with 120 minutes stirring time is $5.8 \mathrm{mekO}_{2} / \mathrm{kg}$. There is the effect of adding avocado seed powder (Persea Americana Mill) which is significant between the time of stirring with a decrease in peroxide number in bulk cooking oil p-value 0.000 .
\end{abstract}

Keywords: cooking oil, avocado seeds, peroxide value

Korespondensi: Nurminha, Jurusan Analis Kesehatan Politeknik Kesehatan Tanjungkarang, Jalan SoekarnoHatta No. 1 Bandar Lampung, mobile 082185063737, e-mail nurminha@ poltekkes-tjk.ac.id 


\section{Pendahuluan}

Lemak dan minyak adalah salah satu kelompok yang termasuk golongan lipid yang dihasilkan oleh alam bersumber dari bahan nabati dan hewani. Satu sifat khas dan mencirikan golongan lipida (minyak dan lemak) adalah daya larutnya dalam pelarut organik atau sebaliknya tidak larut dalam pelarut air. Hal ini disebabkan oleh adanya asam lemak berantai karbon panjang dan adanya gugus-gugus polar (Sudarmadji, 2010). Dalam teknologi makanan, minyak memegang peran penting karena minyak memiliki titik didih yang tinggi sekitar $200^{\circ} \mathrm{C}$ maka bisa dipergunakan untuk menggoreng makanan sehingga bahan yang digoreng akan kehilangan sebagian besar air yang dikandungnya dan menjadi kering (Sudarmadji, 2010).

Minyak goreng merupakan salah satu bahan menggoreng yang banyak digunakan oleh masyarakat, dimana sebagian besar menu masyarakat merupakan bahan yang digoreng. Minyak goreng yang digunakan ibu rumah tangga sebagian besar digunakan secara berulang. Minyak goreng yang digunakan secara berulang dengan pemanasan yang terlalu lama dapat menyebabkan ikatan rangkap pada minyak goreng teroksidasi sehingga membentuk gugus peroksida yang ditandai dengan meningkatnya bilangan peroksida (Winarno, 2004). Minyak goreng yang digunakan berkali-kali akan mengalami oksidasi (reaksi dengan udara), hal ini dapat menyebabkan iritasi saluran pencernaan, diare, dan kanker. Selain itu minyak goreng tersebut juga mengalami ketengikan hingga merusak tekstur dan cita rasa bahan makanan yang digoreng (Khomsam, 2003). Selain oksidasi selama proses penggorengan juga terjadi hidrolisis minyak sehingga menghasilkan gliserol dan asam lemak bebas.

Standar Nasional Indonesia (SNI) 37412013 memberikan batasan maksimal bilangan peroksida pada minyak goreng adalah 10 mek $\mathrm{O}_{2} / \mathrm{kg}$. Bilangan Peroksida adalah indeks jumlah lemak atau minyak yang telah mengalami oksidasi, angka peroksida sangat penting untuk identifikasi tingkat oksidasi minyak. Efek negatif yang terjadi pada manusia jika mengkonsumsi minyak goreng dengan kandungan bilangan peroksida berlebih akan menyebabkan kebutuhan vitamin $\mathrm{E}$ yang lebih besar, kekurangan vitamin $\mathrm{E}$ dalam lemak mengakibatkan timbulnya gejala encephalomalacia jika terjadi hidroperoksida dalam aliran darah menimbulkan gejala celebllar. Peroksida akan membentuk persenyawaan lipoperoksida secara non enzimatis dalam otot, usus dan mitokondria.

Lipoperoksida dalam aliran darah mengakibatkan denaturasi lipoprotein yang mempunyai kerapatan rendah. Lipoprotein dalam keadaan normal mempunyai fungsi aktif sebagai alat transfortasi trigliserida dan pada saat lipoprotein mengalami denaturasi akan mengakibatkan deposisi lemak dalam pembuluh darah (aorta) sehingga menimbulkan gejala aterosklerosis (Ketaren, 2012).

Kerusakan minyak dapat berpengaruh pada mutu dan gizi bahan pangan yang digoreng serta dapat berdampak pada kesehatan. Konsumsi minyak yang mengandung peroksida akan membentuk radikal bebas di dalam tubuh. Radikal bebas merupakan senyawa yang berbahaya bagi kesehatan tubuh karena dapat menyebabkan kerusakan DNA sel, kematian sel dan berpotensi menimbulkan kanker. Radikal bebas dapat memicu terjadinya kanker paru, kanker kulit, kanker kolon, dan kanker esophagus (Rohmawati S, 2017). Kerusakan minyak akibat oksidasi dapat diatasi dengan menambahkan antioksidan,

Berdasarkan sumbernya terdapat tiga jenis antioksidan yaitu antioksidan yang berasal dari dalam tubuh, antioksidan sintetik, dan antioksidan alami. Antioksidan sintetik banyak digunakan oleh industri pangan yaitu Butil Hidroksitoluen (BHT) karena harganya murah, cukup efektif mencegah oksidasi namun jika melebihi batas dapat bersifat karsinogenik (Cahyadi, 2008). Salah satu cara mengatasi hal tersebut dengan menggunakan antioksidan alami. Sumber antioksidan alami banyak terdapat pada bahan makanan dan tanaman obat.

Indonesia merupakan salah satu Negara agraris yang kaya akan sumber daya alam yang berpotensi besar sebagai penghasil sumber antioksidan alami. Beberapa jenis tanaman obat yang mengandung antioksidan alami antara lain tokoferol, bawang merah, bawang putih, sirih merah, sirih hijau dan kulit pisang kepok dan biji alpukat (Agoes, Azwar, 2010). Penelitian yang dilakukan Rohmawati (2017) didapatkan hasil uji $\mathrm{F}$ menunjukan penambahan bawang merah ataupun bawang memiliki efektifitas sama terhadap penurunan bilangan peroksida ( $p$ value $=0,722$ ). Penelitian oleh Ferdinan A, dkk (2017) Kulit buah pisang kapok dapat menurunkan angka peroksida dengan variasi waktu perendaman 1, 2, 3 dan 4 jam. Buah alpukat merupakan tanaman yang dapat tumbuh 
subur di daerah tropis Indonesi. Buah alpukat banyak digemari orang yang bergizi tinggi rasanya lezat dan kaya antioksidan.

Masyarakat pada umumnya hanya memanfaatkan buahnya saja sedangkan biji alpukat hanya dibuang sebagai limbah. Biji alpukat mempunyai efek hipoglikemik dan dapat digunakan untuk pengobatan secara tradisional dengan cara dikeringkan dan dihaluskan, air seduhannya dapat diminum. Biji alpukat dipercaya dapat mengobati sakit gigi, mag kronis, hipertensi dan diabetes mellitus (Monica, 2006).

Beberapa penelitian menunjukan biji alpukat memiliki khasiat antidiabetes. Hasil skrining fitokimia yang dilakukan oleh Zuhrotun (2007) terhadap simplisia dan ekstrak etanol biji alpukat menunjukkan bahwa biji alpukat mengandung polifenol, flavonoid, triterfenoid, kuinon, saponin, tannin, monoterpenoid dan seskuiterpenoid yang memiliki sifat anti bakteri. Tannin merupakan senyawa aktif metabolit sekunder yang diketahui mempunya beberapa khasiat yaitu astringen, anti diare, antibakteri dan antioksidan.

Antioksidan dalam pengertian kimia, merupakan senyawa pemberi elektron. Antioksidan bekerja dengan cara mendonorkan satu elektronnya kepada senyawa yang bersifat oksidan sehingga aktivitas senyawa oksidan tersebut bisa terhambat. Oksidan menstabilkan radikal bebas dengan melengkapi kekurangan electron yang dimiliki radikal bebas dan menghambat terjadinya reaksi berantai dari pembentukan radikal bebas ( Winarsi, 2007). Radikal bebas dapat bereaksi dengan $\mathrm{O} 2$ membentuk peroksida aktif yang berbahaya dalam minyak akibat pemanasan berulang. Penelitian Liber P (2012) didapatkan kandungan tanin padabiji alpikat mentega kering $16,99 \mathrm{mg} / \mathrm{kg}$ dan biji alpukat biasa kering 20,855 mg/kg dan aktivitas antioksidan tertinggi pada biji alpukat mentega kering $92,97 \%$ dan biji alpukat biasa kering 93,045\%. Biji alpukat memiliki kadar antioksidan tinggi sehingga dapat digunakan sebagai salah satu sumber antioksidan alami. Penelitian yang dilakukan oleh Marlina (2015) penambahan antioksidan alami ekstrak kulit manggis dengan jumlah 0,5 g sampai 2,2g pada minyak goreng bekas pakai dengan variasi waktu pengadukan $10,20,30,40,50$ menit, mampu menurunkan bilangan asam $0,27 \%$ dan bilangan peroksida 2 mek/kg. Rumusan masalah pada penelitian ini adalah bagaimanakah pengaruh penambahan serbuk biji alpukat (Persea Americana Mill) terhadap penurunan bilangan peroksida pada minyak goreng curah? Tujuan penelitian ini adalah untuk mengetahui pengaruh antara waktu pengadukan dengan bilangan peroksida untuk berbagai konsentrasi serbuk biji alpukat (Persea Americana Mill).

\section{Metode}

Jenis penelitian adalah eksperimen. Rancangan penelitian ini adalah quasi eksperimen. Variabel Dependen (bebas) penelitian ini adalah minyak goreng curah dan serbuk biji alpukat. Variabel Independen (terikat) adalah bilangan peroksida. Tempat penelitian ini dilakukan di Laboratorium Kimia Analisa Makanan dan Minuman Jurusan Analis Kesehatan Tanjungkarang. Penelitian ini dilakukan pada bulan Mei - November 2018. Subyek penelitian ini adalah minyak goreng curah sebelum digunakan untuk menggoreng dan minyak goreng curah yang telah digunakan untuk menggoreng berulang di rumah tangga. Serbuk biji alpukat dengan 6 konsentrasi yaitu $5 ; 10 ; 15 ; 20 ; 30$ dan $40 \%$. dan lama waktu pengadukan 30; 60; 90; 120 menit.

Prosedur penelitian diawali dengan pembuatan serbuk biji alpukat dengan cara buah alpukat yang matang dipisahkan biji dari dagingnya lapisan kulit biji alpukat dibuang. Biji alpukat diiris tipis-tipis $2 \mathrm{ml}$ dan dipotong kecil-kecil ukuran $1 \mathrm{~cm}$, dijemur sampai kering dan ditumbuk dengan mortar sampai halus (Liber P, 2012). Persipan sampel minyak dilakukan sebagai berikut: disiapkan minyak goreng curah sebanyak $6 \mathrm{~L}$ yang dibeli di pasaran digunakan sebagai sampel diberikan pada ibu rumah tangga untuk digunakan dengan pemanasan secara berulang-ulang. Dipisahkan $250 \mathrm{ml}$ untuk diperiksa langsung bilangan peroksidanya. Minyak yang telah digunakan secara berulang-ulang dimasukkan ke dalam gelas beaker masing-masing sebanyak $250 \mathrm{ml}$ untuk dilakukan percobaan menggunakan bahan antioksidan (serbuk biji alpukat) dengan konsentrasi $0 ; 5 ; 10 ; 15 ; 20 ; 30$ dan $40 \%$. Masing-masing sampel ditutup dengan wadah sampel tertutup menggunakan kertas karbon dengan rapat menggunakan plastik pada ruangan tertutup dan suhu kamar, sehingga tidak ada proses hidrolisis, oksidasi dan ketengikan yang terjadi terhadap pengaruh yang berpotensi merusak minyak. Selanjutnya dihomogenkan menggunakan pengaduk/rotator sesuai waktu yang ditentukan; masing- masing konsentrasi dilakukan pengadukan dengan perlakuan $0,30,60,90$ dan 120 menit. 
Kemudian dilakukan pemeriksaan bilangan peroksida dengan metode Jodometri sesuai SNI 3471 : 2013 sebagai berikut: minyak ditimbang sebanyak 5,0 g dan dimasukkan kedalam labu Erlenmeyer $250 \mathrm{ml}$ tertutup. Kemudian ditambahkan $30 \mathrm{ml}$ larutan asam asetat glacialkloroform (3:2), di kocok sampai bahan terlarut semua. Selanjutnya ditambahkan $1 \mathrm{ml}$ larutan jenuh kalium iodide dihomogen kan dan didiamkan selama 10 menit. Setelah itu ditambahkan $100 \mathrm{ml}$ aquadest, campuran dititrasi dengan $\mathrm{Na}_{2} \mathrm{~S}_{2} \mathrm{O}_{3} 0,050 \mathrm{~N}$ sampai warna kuning jerami. Ditambahkan larutan amilum dan di titrasi kembali sampai warna biru tepat hilang. Dihitung angkat peroksida yang dinyatakan dalam mili-ekuivalen dari peroksida dalam $1000 \mathrm{~g}$ sampel. Penetapan blanko menggunakan $30 \mathrm{ml}$ larutan asam asetat glacialkloroform.

\section{Hasil}

Hasil penelitian disajikan pada tabel dibawah ini:

Tabel 1. Kadar Bilangan Peroksida Sebelum dan Setelah Pemanasan

\begin{tabular}{lc}
\hline \multicolumn{1}{c}{$\begin{array}{c}\text { Minyak Goreng } \\
\text { Curah }\end{array}$} & $\begin{array}{c}\text { Kadar Bilangan } \\
\text { Peroksida (mekO2/Kg) }\end{array}$ \\
\hline Sebelum Pemanasan & 4,85 \\
Setelah Pemanasan & 18,56 \\
\hline
\end{tabular}

Tabel 2. Rata-rata hasil bilangan peroksida setelah penambahan serbuk biji alpukat (persea Americana Mill)

\begin{tabular}{ccccccc}
\hline \multirow{2}{*}{ Waktu Pengadukan (Menit) } & \multicolumn{7}{c}{ Konsentrasi Serbuk Biji Alpukat (\%) } \\
\cline { 2 - 7 } & $\mathbf{5}$ & $\mathbf{1 0}$ & $\mathbf{1 5}$ & $\mathbf{2 0}$ & $\mathbf{3 0}$ & $\mathbf{4 0}$ \\
\hline 30 & 15,97 & 15,91 & 15,82 & 15,60 & 16,76 & 9,27 \\
60 & 15,31 & 15,22 & 14,94 & 14,83 & 11,84 & 8,07 \\
90 & 14,60 & 14,42 & 14,27 & 14,06 & 10,86 & 8,05 \\
120 & 13,55 & 13,36 & 13,22 & 12,91 & 10,53 & 5,8 \\
\hline
\end{tabular}

Tabel 3. Hubungan Antara Waktu Pengadukan dengan Bilangan Peroksida pada Minyak

\begin{tabular}{cccccc}
\hline Waktu Pengadukan & Mean & SD & Minimum & maksimum & p-value \\
\hline 30 & 14.89 & 2.93 & 6.83 & 17.57 & \\
\cline { 1 - 5 } 60 & 13.37 & 3.13 & 6.79 & 17.11 & \\
\cline { 1 - 5 } 90 & 12.71 & 3.01 & 7.33 & 16.51 & \\
\cline { 1 - 4 } 120 & 11.66 & 3.2 & 4.91 & 15.62 & \\
\hline
\end{tabular}

Tabel 4. Penurunan Bilangan Peroksida pada Minyak Goreng Curah dengan Penambahan Serbuk Biji Alpukat (Persea Americana Milli)

\begin{tabular}{ccccccc}
\hline \multirow{2}{*}{ Waktu Pengadukan (Menit) } & \multicolumn{7}{c}{ Konsentrasi } \\
\cline { 2 - 7 } & $\mathbf{5}$ & $\mathbf{1 0}$ & $\mathbf{1 5}$ & $\mathbf{2 0}$ & $\mathbf{3 0}$ & $\mathbf{4 0}$ \\
\hline 30 & 2,59 & 2,65 & 2,74 & 2,96 & 1,8 & 9,29 \\
60 & 3,25 & 3,34 & 3,62 & 3,73 & 6,72 & 10,49 \\
90 & 3,96 & 4,14 & 4,29 & 4,5 & 7,7 & 10,51 \\
120 & 5,01 & 5,20 & 5,34 & 5,65 & 8,03 & 12,76 \\
\hline
\end{tabular}

\section{Pembahasan}

Bilangan peroksida merupakan nilai terpenting untuk menentukan derajat kerusakan minyak. Minyak goreng curah yang dilakukan pemanasan secara berulang dan terus menerus menyebabkan buruknya mutu minyak. Asam lemak tidak jenuh dapat mengikat oksigen pada ikatan rangkapnya sehingga membentuk peroksida. Frekuensi penggorengan yang makin sering mengakibatkan kandungan peroksida semakin meningkat, karena reaksi oksidasi akibat pemanasan dan adanya paparan udara. Didalam rumah tangga atau pada pedagang gorengan, penggorengan seringkali dilakukan terputus, artinya minyak yang sudah didinginkan kemudian digunakan lagi untuk menggoreng bahan pangan lainnya. Penggorengan terputus ini mengakibatkan kerusakan minyak semakin cepat karena terjadi 
hiperperoksida selama pendinginan (Khomsan, 2013)

Dilihat dari tabel 1 kadar bilangan peroksida yang didapatkan pada minyak goreng curah sebelum digunakan untuk menggoreng (sebelum pemanasan) sebesar $4,85 \mathrm{mekO}_{2} / \mathrm{kg}$. nilai tersebut masih dalam batas Standar Nasional Indonesia (SNI) 3741-2013 yang menyatakan standar bilangan peroksida yang terdapat dalam minyak goreng maksimal 10 mek $\mathrm{O}_{2} / \mathrm{kg}$. Namun setelah proses pemanasan berulang kadar bilangan peroksida semakin tinggi sebesar 18,56 mekO2/kg, tingginya kadar bilangan peroksida disebabkan oleh proses pemanasan yang berulang, suhu yang tinggi, tidak stabil dan pengaruh udara terbuka serta cahaya.

Pada tabel 2. Rata-rata kadar bilangan peroksida minyak goreng curah setelah pemanasan berulang dan diberi penambahan serbuk biji alpukat konsentrasi 5\%; 10\%; 20\%; $30 \%$ dan $40 \%$ dengan waktu pengadukan 30 , 60, 90 dan 120 menit menunjukkan hasil penurunan bervariasi mulai dari konsentrasi $5 \%$ sampai $40 \%$. Namun penurunan bilangan peroksida pada setiap konsentrasi berfluktuasi hal ini dipengaruhi lama waktu pengadukan.

Data pada tabel 1 menunjukkan bahwa disetiap konsentrasi dengan penambahan serbuk biji alpukat dan pengadukan mampu menurunkan bilangan peroksida pada minyak. Penurunan terjadi secara signifikan, sesuai dengan konsentrasi dan waktu pengadukan. penambahan serbuk biji alpukat konsentrasi $40 \%$ dan pengadukan selama 120 menit didapatkan hasil maksimal yaitu 5,8

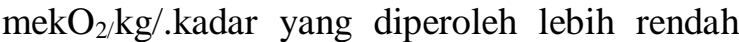
dari batasan SNI. Waktu pengadukan lebih lama mempengaruhi penurunan yang signifikan sehingga bilangan peroksida dapat turun akibat adanya reaksi yang terjadi antara radikal bebas menjadi kurang aktif dan radikal antioksidan tidak mampu melanjutkan rantai oksidasi lebih lanjut sehingga terjadi pemutusan ikatan rangkap. Peristiwa tersebut yang mengakibatkan mekanisme antioksidan dalam menghambat oksidasi/menghentikan reaksi berantai pada radilkal bebas dari lemak yang teroksidasi pada konsentrasi tersebut dan lama pengadukan maksimal diperoleh kadar zat aktif secara maksimal (Sayuti, K dan Rina, 2015)

Berdasarkan hasil yang didapat pengaruh yang terjadi yaitu semakin besar konsentrasi dan lamanya waktu pengadukan sangat mempengaruhi cara kerja antioksidan dalam proses hidrolisis, oksidasi dan hidrogenasi bertujuan untuk menjenuhkan ikatan rangkap dari rantai karbon asam lemak pada minyak atau lemak. Pada tabel 3 didapatkan ada pengaruh penambahan serbuk biji alpukat yang signifikan antara waktu pengadukan dengan penurrunan bilangan peroksida pada minyak goreng curah dengan $p$-value $0.000<0,05$ dengan demikian hipotesis Ho diterima. Hal ini disebabkan serbuk biji alpukat mempunyai kandungan tannin, flavonoid dan aktivitas antioksidan yang tinggi 93,045\% sehingga mampu menurunkan bilangan peroksida (Liber $P$, 2012). Selain itu biji alpukat juga mempunyai khasiat anti bakteri dan anti diabetes (Zuhrotun, 2007).

Penelitian ini hampir sama dengan penelitian oleh Ferdinan A, dkk (2017) bahwa kulit buah pisang kepok mampu menurunkan angka peroksida dengan variasi perendaman 1,2,3 dan 4 jam. Penelitian oleh Marlina (2015) penambahan ekstrak kulit manggis 0,5-2,2 gram pada minyak goreng bekas pakai dengan variasi waktu pengadukan 10, 20, 30, 40 dan 50 menit menurunkan bilangan peroksida 2 mek $\mathrm{O}_{2} / \mathrm{kg}$. Dari hasil penelitian ini serbuk biji alpukat mampu menurunkan bilangan peroksida 9,29 mek $\mathrm{O}_{2} / \mathrm{kg}$.

Menurut Silalahi, J. (2006) alternatif untuk mencegah ketengikan pada minyak, salah satunya adalah dengan penambahan antioksidan. Antioksidan atau reduktor berfungsi untuk mencgah terjadinya oksidasi atau mentralkan senyawa yang telah teroksidasi dengan cara menyumbangkan hidrogen atau elektron. Berdasarkan penelitian yang dilakukan didaptkan bahwa kandungan tannin, flavonoid dan antioksidan yang tinggi pada biji alpukat ini dapat menghambat terjadinya reaksi berantai dari pembentukan radikal bebas (Winarsi, 2007), Radikal bebas dapat bereaksi dengan $\mathrm{O}_{2}$ membentuk peroksida aktif yang berbahaya dalam minyak akibat pemanasan berulang.

Berdasarkan keseluruhan hasil penelitian yang telah dilakukan dapat diketahui bahwa antioksidan yang terdapat pada serbuk biji alpukat yang mengandung senyawa polifenol, flavonoid, saponin dan tannin dapat menurunkan kadar bilangan peroksida yang berbeda tergantung pada tingkatan konsentrasi dan lamanya waktu pengadukan. Pada tabel 4 menunjukan konsentrasi 5\% tidak terjadi penurunan yang berarti disebabkan oleh adanya volume yang sama pada keseluruhan percobaan yaitu $250 \mathrm{ml}$. sehingga pada saat konsentrasi rendah dan pengadukan tidak terlalu lama belum menunjukkan penurunan yang signifikan. Lain halnya dengan perlakuan 
konsentrasi yang besar yaitu $40 \%$, dengan lama pengadukan 30 menit sampai 120 menit sudah menunjukan penurunan yang signifikan dengan penurunan terbesar 12,76 mek $\mathrm{O}_{2} / \mathrm{kg}$ sehingga bilangan peroksida dapat turun secara maksimal akibat adanya reaksi yang terjadi antara radikal bebas menjadi kurang aktif dan radikal antioksidan yang terbentuk tidak mampu melanjutkan rantai oksidasi lebih lanjut sehingga terjadi pemutusan ikatan rangkap, hai itu mengakibatkan mekanisme antioksidan dalam penghambat oksidasi atau menghentikan reaksi berantai pada radikal bebas dari lemak yang teroksidasi pada konsentrasi tersebut dan lama waktu pengadukan yang maksimal diperoleh pula kadar zat aktif secara maksimal.

Penelitian ini menyatakan lama pengadukan berpengaruh pada penurunan bilangann peroksida karena dengan adanya aktivitas pengadukan akan mempercepat reaksi antara antioksidan didalam serbuk biji alpukat dapat menghambat reaksi oksidasi yang terjadi pada minyak goreng. Semakin lama pengadukan maka bilangan peroksida akan menurun. Sedangkan besar konsentrasi yang digunakan juga berpengaruh dengan penurunan bilangan peroksida karena semakin besar konsentrasi serbuk biji alpukat yang dipakai untuk menurunkan bilangan peroksida dalam minyak goreng.

Simpulan pada penelitian ini adalah bilangan peroksida pada minyak goreng curah sebelum pemanasan adalah 4,85 mek $\mathrm{O}_{2} / \mathrm{kg}$ dan setelah pemanasan 18,56 mek $\mathrm{O}_{2} / \mathrm{kg}$ pada minyak goreng curah sebelum diberi perlakuan dengan serbuk biji alpukat (Persea Americana Mill). Bilangan peroksida pada minyak goreng curah setelah penambahan serbuk biji alpukat (Persea Americana Mill) hasil maksimal pada konsentari $40 \%$ dengan waktu pengadukan 120 menit yaitu 5,8 mekO $\mathrm{m}_{2 / \mathrm{kg}}$ dengan penurunan sebesar 12,76 mek $\mathrm{O}_{2} / \mathrm{kg}$. Ada pengaruh penambahan serbuk biji alpukat (Persea Americana Mill) yang signifikan antara waktu pengadukan dengan penurunan bilangan peroksida pada minyak goreng curah $\mathrm{p}$-value 0.000 .

Saran pada penelitian ini adalah serbuk biji alpukat (Persea Americana Mill) dapat digunakan sebagai saalah satu antioksidan alami. Masyarakat tidak menggunakan minyak untuk menggoreng secara berulang lebih dari 4 kali pengulangan karena dapat meningkatkan bilangan peroksida yang ada dalam minyak. Dan pemanasan minyak goreng tidak digunakan pada suhu yang tinggi karena dapat menyebabkan oksidasi dan meningkatkan bilangan peroksida.

\section{Daftar Pustaka}

Agoes, Azwar, 2010, Tanaman Obat Indonesia, Jakarta Salemba, Medika.

Cahyadi, W, 2008, Analisis dan Aspek Kesehatan Bahan Tambahan Pangan, Bumi Aksara, Jakarta.

Ferdinan, F, 2017, Penurunan Bilangan Peroksida dengan Kulit Pisang Kepok, Jurnal Ilmiah Ibnu Sina, 2(1), 117-121

Kataren , S, 2012, Minyak dan Lemak Pangan Universitas Indonesia, Jakarta.

Khomsan, A, 2013, Pangan dan Gizi Untuk Kesehatan,Raja Gravindo Persada, Jakarta.

Liberty P, Sangi ,MS, Paendong J, 2012. penentuan Kandungan Tanin dan Uji Aktivitas Antioksidan Ekstrak Biji Buah Alpukat (Persea Americana Mill) Jurnal Kimia Mipa Unsrat,Manado

Marlina, L, 2015, Pengaruh Penambahan Ekstrak Kulit Manggis Terhadap Ketahanan Oksidasi Minyak Goreng Curah, Jakarta. Institut Teknologi Indonesia

Monica, F, 2006, pengaruh Pemberian Serbuk Biji Alpukat Terhadap Kadar ula Darah Tikus Wistar Yang Diberi Beban Glukosa, Universitas Diponegoro Semarang.

Rohmawati, S, Pangestu , DR, Wijayanti., 2017. Perbedaan Jumlah Bilangan Peroksida Minyak Goreng Dengan Penambahan Bawang Merah dan Bawang Putih Sebagai Antioksidan Alami. Jurnal Kesehatan Masyarakat, Vol 5 No1 Januari 2017

Sayuti, K, dan Rina, 2015, Antioksidan Alami dan Sintetik, Andalas University Press, Padang.

Silalahi, J. 2006, Makanan Fungsional, Kanasius, Yogyakarta 
Standar Nasional Indonesia, 2013, Minyak Goreng, SNI. No. 3741-2013, Badan Standarisasi Nasional.

Sudarmadji, S, Haryono, S, Suhardi, 2010, Analisa Bahan Makanan dan Pertanian, Liberty Yogyakarta, Yogyakarta.

Winarno, FG, 2004, Kimia Pangan dan Gizi, PT Gramedia Utama, Jakarta.

Winarsi, H, 2007, Antioksidan Alami dan Radikal Bebas, Kanisus Jakarta.

Zuhrotun, A, 2007, Aktivitas Antidiabetes Ekstrak Etanol Biji Buah Alpukat (Persea Americana Mill) Bentuk Bulat, Universitas Pajajaran, Bandung. 